\title{
かで形誘導電動機の回転時同期トルクの 解析
}

\author{
正員穴澤義 久(秋田大) \\ 正員藤 原一（北海道大）
}

\section{1. まえがき}

電気機械の統一理論の発展により，電気機械は L.C.R.M の回路網として解析できるようになった (1) (4)。しかし，統一理諭に扔いて报っている空間高 調波は，突極性に基づくパーミアンス分布の基本波の みであり，起磁力の高調波やみぞの存在によるパーミ アンスの変化てついてはすべて無視されてきた。

統一理論による空間高調诐の解析に関しては，反作 用電動機の高調波トルクについて加藤氏らによってな されている(5)ー(7)。かで形誘学電動機の高調波異常現

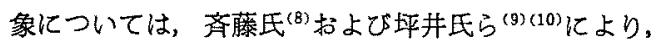
分布巻汇起因する各高調波成分のみを考慮した解析が なされている。しかし，スロットの存在による空计き パーミアンスの変化化ついては触れられていない。

かで形誘導機の高調波異常現象の解析に扣いてスロ ットの存在による空げきパーミアンス分布の変化は無 視しうるものではなく，起磁力分布に含まれる高調波 と共に考慮しなければ，高嘼波同期および非同期トル クを定量的に解析できないととは明らかである(11)(12)。

本研究はこれまで統一理論において無視されてきた スロットの影響を，統一理論へ導入するてとを目的と

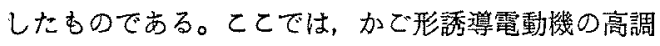
波異常現象のうち，回転時同期トルクを発生するとさ れている偶数みぞ数について解析した。すなわち，巻 線の配置と空げきパーミアンス分布よりインダクタン ス行列を計算し，てれより対称座標軸上の電壬方程式 を導き，トルクの一般式を求めた(14)。更に, 本解析結 果が実験值とよい一致をみせていることを明らかにし た(14)。

本研究は, 統一理論へスロットの影響を導入するて とにより，誘導機の高調波トルクの解析に有効な゙手法 とした。また,トルクの一般式が従来の解析結果より

An Analysis of Synchronous Crawling in Induction Motors. By Yoshihisa Anazawa, Member, (Faculty of Mining, Akita University), Hajime Fujiztara, Member (Faculty of Engineering, Hokkaido University)

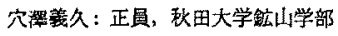
醉原 一：正員, 北海道大学工学部

昭 $54-1$

\begin{tabular}{|cc|}
\hline 論 & 文 \\
\hline $54-\mathbf{B} 3$ \\
\hline
\end{tabular}

簡潔な形で明確に表現できるようになった。

回転子みぞ数が奇数となる場合は，磁気回路が非対 称となり，空げきの磁束密度分布の計算に特別の考虑 が必要となり ${ }^{(15)}$, 現在検討中である。

\section{2. インダクタンス}

解析に用いる電勘機は二椣で固定子みぞ数が $S$ ，回 転子みぞ数がR，また各椙が平衡していてその中性線 屾非接続しする。

〈2・1〉パーミアンス分布 第1四のように $a$ 相 巻線軸と 1 番目の回転子菌とのなず角度を $\theta^{\prime}$ ，空げき

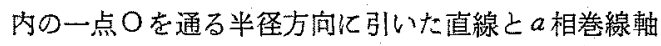
とのなす角度を $\theta$ ，○を通る直線と 1 番目の菌とのな す角度を $\varphi$ とする。磁気抵抗 $R$ は空げき長に比例す るので, $\theta$ と $\varphi$ 関数として (1)式で表わされる。

$\mathscr{R}=\mathscr{R}_{0}+\sum_{m} \mathscr{R}_{m S} \cos m S \theta+\sum_{n} \mathcal{R}_{n R} \cos n R \varphi$

但し, $\mathscr{R}_{0}:$ 磁気抵抗の平均值， $\mathscr{R}_{m} S, \mathscr{R}_{n R}$ :

各々固定子，回転子遴による磁気抵杭の変化

分の $m, n$ 次成分, $m, n:$ 正の整数

パーミアンス分布は磁気抵抗の逆数として求まり， 級数に展開し整理すると(2)式となる。

$$
\begin{aligned}
& P(\theta, \varphi)=\sum_{m n} P_{m S n R} \cos (m S \theta \pm n R \varphi) \ldots( \\
& \text { 但し } \theta=\theta^{\prime}+\varphi
\end{aligned}
$$

この結果は尾本・石崎氏の計算と同様になり(11), パー

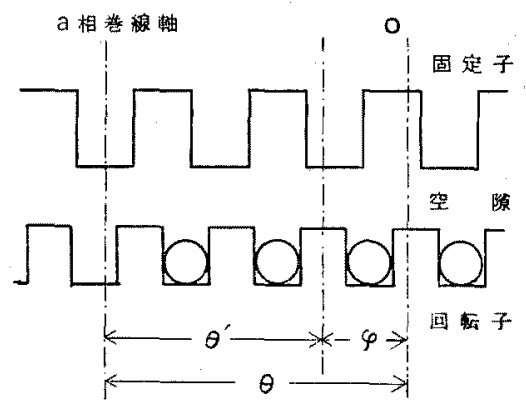

第 1 图 誘導篦勳幾之座標

Fig. 1. Induction motor and coodinates. 
ミアンス分布は $(m S \pm n R)$ 次で变化する成分の和上 して裁わされる。但し， $m, n$ 如零を含む正の整数て ある。

$\langle 2 \cdot 2\rangle$ 起磁力分布起磁力分布仙，電流之美線 分布を知るととによりフーリエ級数に屡開でき，固定 子 $k$ 相巻線の起磁力 $F_{1 k}(\theta)$ 怯 $(3)$ 式上なる。

$$
F_{1 k}(\theta)=\sum_{l} F_{1 l} \cos l\{\theta-(k-1) \alpha\}
$$

但し, $\alpha=2 \pi / 3, l:$ 正の整数

かご形巻線は，二次導体数之等しい相数の星形対称多 相巻線とみなせ，その有効巻数は $1 / 2$ になる。 $k$ 番 目導体汇上る起磁力分布は (4) 式となる。

$$
\begin{aligned}
& F_{2 k}(\varphi)=\sum_{i} F_{2 l} \cos l\{\varphi-\beta-(k-1) \gamma\} \\
& \text { 但し, } \gamma=2 \pi / R, \beta=(-\pi+\gamma) / 2
\end{aligned}
$$

〈2.3〉磁束密度分布 起磁力は空げき内です心 て半径方向に作用し，空げき長は回転子外径化対して 十分小さいと仮定すると，磁束密度分布はパーミアン スと起磁力の皘で表和される。固定子 $k$ 相巻線を励磁 したときの磁束密度分布は(5)式となる。

$$
B\left(\theta, \theta^{\prime}\right)=P\left(\theta, \theta^{\prime}\right) \cdot F_{1 k}(\theta)
$$

〈2・4〉インダクタンス 固定子 $k$ 相巻線が励磁 されているときの固定子 $g$ 相巻線の磁束銷交数は (6) 式となる。

$$
\phi=w \cdot u \int_{-2 / \pi+(g-1) \alpha}^{2 / \pi+(g-1) \alpha} B\left(\theta, \theta^{\prime}\right) \cdot \gamma \cdot d \theta . .
$$

但し, $w$ ：巻数, $w$ : 鉄心長, $r:$ 回鞋子半径 (6)式より固定子巻線の自己インダクタンス $L_{1 q k}\left(\theta^{\prime}\right)$ が求まり $(7)$ 式となる。

$$
\begin{aligned}
& L_{1 g k}\left(\theta^{\prime}\right)=\sum_{m n l} L_{1\left(m S_{ \pm} n R\right) l} \cos \{(m S \pm n R \\
& \left.+l)(g-1) \alpha \mp n R \theta^{\prime}-l(k-1) \alpha\right\} \\
& +\sum_{m n l} L_{1(m S \pm n R) l^{\prime}} \cos \{(m S \pm n R- \\
& \text { l) } \left.(g-1) \alpha \mp n R \theta^{\prime}+l(k-1) \alpha\right\}
\end{aligned}
$$

但し，符号同順上する。固定子卷線の自己インダクタ ンスは，回転子みぞの存在に上り回転子の位置角 $\theta^{\prime}$ の $n R$ 倍の周期で変化する成分が含まれ，乙の成分 が固定子逆相回路䎲 $n R$ 次の高調波すべり周波数電 流を流し，高調波同期トルクおよびそれ付随する高 調波非同期トルク口発生原因上なる。（7)式仙 $R$ 極 をむつ多相反作用電動機の電機子巻線のインダクタン 不之等しい。高調波次数は $(m S \pm n R \pm l)$ 次上なり， これらのうち基本波とみぞ高調波成分が他上比較して 大きな值を有する。 $m=n=0$ は空げきが平滑，すな わち起磁力に含まれる高調波のみを考慮したインダタ タンスとなる。
回転子巻線の自己インダクタンスは，

$$
\begin{aligned}
L_{20 k}\left(\theta^{\prime}\right)= & \sum_{m n l} L_{2(m S \pm n R) l} \cos \left\{m S \theta^{\prime}+(m S\right. \\
& \pm n R+l)(\beta+\overline{g-1} \cdot r)-l(\beta \\
& +\overline{k-1} \cdot r)\}+\sum_{m n l} L_{2(m S \pm n R) l^{\prime} \cos } \\
& \times\left\{m S \theta^{\prime}+(m S \pm n R-l)(\beta\right. \\
& +\overline{g-1} \cdot r)+l(\beta+\overline{k-1} \cdot r)\}
\end{aligned}
$$

となり，固定子巻線の自己インダクタンスとは逆に， 固定子みぞの影響により $m S \theta^{\prime}$ で変化する成分が含ま れる。乙の成分は，回転子の高調波すべり周波数回路 を結合する相互インダクタンスとなる。

固定子巻線加回転子巻線への相互インダクタンス は (9)式となる。

$$
\begin{aligned}
M_{g k}\left(\theta^{\prime}\right)= & \sum_{m n l} M_{(m S \pm n R) l} \cos \left\{(m S+l) \theta^{\prime}\right. \\
& +(m S \pm n R+l)(\beta+\overline{g-1} \cdot \gamma) \\
& -l(k-1) \alpha\}+\sum_{m n l} M_{\left(m S_{ \pm n R}\right) l^{\prime}} \cos \\
& \times\left\{(m s-l) \theta^{\prime}+(m S \pm n R-l)\right. \\
& \times(\overline{\beta+g}-1 \gamma)+l(k-1) \alpha\} \ldots(9)
\end{aligned}
$$

高調波次数は $(m S \pm n R \pm l)$ 次であるが，回転子の位 置角 $\theta^{\prime}$ に関しては $(m S \pm l)$ 次となる。 $m=n=0$ は 起磁力の高調波の及考慮しだ相互インダクタンスとな り，乙の場合回転子の位監角 $\theta^{\prime}$ を变数之す百成分は 相互インダクタンスのみに現わ执る。

\section{3. 対称座標变換}

前章で求めたインダクタンス行列老対称座標変换す る上，自己扰よび相互インダクタンスの $(\delta, \varepsilon)$ 要素は (10)式となる。

$$
\left.\begin{array}{l}
L_{1 \delta \varepsilon}\left(\theta^{\prime}\right)=\sum_{g=1}^{3} \sum_{k=1}^{3} a_{\delta \theta} \cdot L_{1 g k}\left(\theta^{\prime}\right) \cdot a_{k \varepsilon} * / 3 \\
L_{2 \delta \varepsilon}\left(\theta^{\prime}\right)=\sum_{g=1}^{R} \sum_{k=1}^{R} b_{\delta \theta} \cdot L_{2 q k}\left(\theta^{\prime}\right) \cdot b_{k \varepsilon} * / R \\
M_{\delta \varepsilon}\left(\theta^{\prime}\right)=\sum_{g=1}^{R} \sum_{k=1}^{3} b_{\delta \theta} \cdot M_{g k}\left(\theta^{\prime}\right) \cdot a_{k \varepsilon} * / \sqrt{3 R}
\end{array}\right\}
$$

但し,

$$
\begin{array}{ll}
a_{\delta g}=a^{(g-1)(\delta-1)} & a=\varepsilon^{j \alpha} \\
b_{\delta g}=b^{(g-1)(\delta-1)} & b=\varepsilon^{j \gamma} .
\end{array}
$$

(10)式より，対称座標変換さ㧈た固定子巻線自己イン ダクタンス行列 ( $L_{1 A}$ )は(11)式となる。

$$
\begin{aligned}
\left\lceil L_{1 A}\right]= & \sum_{m n l} \frac{3}{2}\left\{L _ { 1 ( m \pm n R ) l } \left(\varepsilon^{j n R \theta^{\prime}} \cdot\left[C_{\zeta \delta}\right]\right.\right. \\
& \left.+\varepsilon^{-j n R \theta^{\prime}}\left[C_{\eta \varepsilon}\right]\right)
\end{aligned}
$$




$$
\begin{aligned}
& +L_{1}{ }^{\prime}(m \pm n R) l^{\prime}\left(\varepsilon^{j n R \theta^{\prime}}\left[\varepsilon^{(\varepsilon}\right]+\varepsilon^{-j n R \theta^{\prime}}\right. \\
& \left.\left.\cdot\left\{C_{\kappa \delta}\right]\right)\right\} \quad \ldots \ldots \ldots \ldots \ldots \ldots \ldots \ldots(11)
\end{aligned}
$$

行列 $\left[C_{\xi \delta}\right] \cdots\left[C^{\kappa_{\delta}}\right]$ は $(\zeta, \delta) \cdots(\kappa, \delta)$ に 1 の值の要 素を持ち，その他の要素は零である。 $\delta, \varepsilon \cdots \kappa$ は (12) 式によって与えられる(13)。

$$
\left.\begin{array}{l}
\delta=3 \chi+l+1, \quad \varepsilon=3 \chi-l+1 \\
\zeta=3 \chi \pm(m S \pm n R+l)+1 \\
\eta=3 \chi \mp(m S \pm n R+l)+1 \\
\iota=3 \chi \pm(m S \pm n R-l)+1 \\
\kappa=3 \chi \mp(m S \pm n R-l)+1
\end{array}\right)
$$

但し, $\chi=0, \pm 1, \pm 2 \cdots \cdots \cdots, 3 \geqq \delta, \varepsilon, \cdots \kappa \geqq 1$ すなわち， $\delta ， \varepsilon ， \cdots \kappa$ 吕 1〜3 の整数㥀をとるように

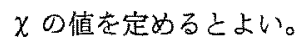

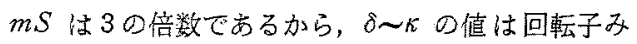
ぞによるパーミアンスの高調波次数 $n$ 之起磁力の高調 波次数しによって定まることが(12)式より判明する。 特に, $n R$ か 3 の倍数の場合, 対称座標変換した固定 子巻線自己インダクタンスは対角要素となる。これは， 静止時同期トルクを発生するみぞ数であり，単相反作 用トルクを生じる成分ではあるか，乙の成分は固定子 正相回路に $6 n$ 次のず゙り周波数電流を流し, 乙の電 流成分之固定子逆相および回転子回路の高調波すべり 周波数電流の結合という困難な問題を引き起こすの で，回転子みぞが 6 の倍数である場合は解析の対称か ら除き別に考察するととにする。

中性線は接続されていないので零相回路を除き，

（11）式を整理すると，固定子巻線自己インダクタンス 行列は (13)式となり, 多相反作用電動機の電機子巻線 のインダクタンスと同じ表現となる(6)。

$$
\begin{aligned}
& \left\lceil L_{1 A}\right]=\sum_{h=-\infty}^{\infty} 1 f \frac{1 f}{\frac{L_{1 f}}{L_{1(3 h+1) R} \epsilon^{-j(3 h+1) R \theta^{\prime}}}} \\
& 1 b \\
& \times \frac{L_{1(3 h+1) R} \varepsilon^{j(3 h+1) R \theta^{\prime}}}{L_{1 b}} \\
& L_{1(3 h+1) R}=\sum_{m i} \frac{3}{2} P_{m s(3 h+1) R} \cdot \frac{2 w^{2} u r}{\pi} \\
& \times \frac{k_{d}(6 i+1)}{6 i+1} \sin \frac{(6 i+1) \pi}{2} \\
& \times\left\{\frac{k_{d}(m S+\overline{3 h+1} R-\overline{6 i+1})}{m s+(3 h+1) R-(6 i+1)}\right. \\
& \times \sin \frac{\{m S+(3 h+1) R-(6 i+1)\} \pi}{2}
\end{aligned}
$$

$$
\begin{gathered}
+\frac{k d(m S-\overline{3 h+1} R+\overline{6 i+1})}{m S-(3 h+1) R+6 i+1} \\
\left.\times \sin \frac{\{m S-(3 h+1) R+(6 i+1)\} \pi}{2}\right\}
\end{gathered}
$$

但し, $k_{d}(6 i+1)$ は $(6 i+1)$ 次高調波に詨する分布 巻俰数， $R=6 g+2 ， g ， h ， i$ は雾を含む正㧍よび負 の整数とする。回転子みぞ数が $4,10,16 \cdots$ の場合 $R$ は負の值を有するすのとする。

(14) 式より固定子みぞ数之回転子みぞ数の差が極数 であるときすなわち $R=S \pm 2$ の場合 $L_{1 R}$ が他のみ そ数と比较して大きな值を有することがわかる。

回転子巻線の自己インダタタンスは(15)式のように 変換される。

$$
\begin{aligned}
& \left\lceil L_{2 A}\right]=\sum_{m n l} \frac{R}{2} \times\left\{L_{2(m S \pm n R) l}\right. \\
& \times\left(\varepsilon^{j\left(m S \theta^{\prime}+(m S \pm n R) \beta\right)} \cdot\left[C_{5} \delta\right]\right. \\
& \left.+\varepsilon^{-j\left(m S \theta^{\prime}+(m S \pm n R) \beta\right\}} \cdot\left[C_{\eta \varepsilon}\right]\right) \\
& +L_{2}{ }^{\prime}(m S \pm n R) l^{\prime}\left(\varepsilon^{j\left(m S \theta^{\prime}+(m S \pm n R) \beta\right)}\right. \\
& \text { - } \left.\left.\left\{C_{\varepsilon \varepsilon}\right]+\varepsilon^{-\jmath\left(m S \theta^{\prime}+(m S \pm n R) \beta\right.}\left\{C_{\kappa \delta}\right]\right)\right\} \\
& \delta=\chi R-l+1, \quad \varepsilon=\chi R+l+1 \\
& \zeta=\chi R-(m S \pm n R+l)+1 \\
& \eta=\chi R+(m S \pm n R+l)+1 \\
& \iota=\chi R-(m S \pm n R-l)+1 \\
& \kappa=\chi R+(m S \pm n R+l)+1 \\
& \text { 但し, } R \geqq \delta, \varepsilon \cdots \kappa \geqq 1
\end{aligned}
$$

(16)式より， $m=0$ または $m S$ が $R$ の倍数となる堭合 は対角要素となり，その他の場合は相互要素となる。 対角要素のうち $m \neq 0$ の成分は固定子巻線の自己イン ダクタンスと同様に単相反作用トルクを発生する成分 となる。しかし，Rが 6 の倍数となる場合を除いてい るので，乙の成分は無視してむむしつかえない。

起磁力の高調波次数 $l$ を(17)式とおいて(15)式を整 理すると， $L_{2 m S} \varepsilon^{j m S\left(\theta^{\prime}+\beta\right)}$ は $(\nu, \xi)$ 要素, $L_{2 m S} \varepsilon^{-i m S}$ ${ }^{(\theta+\beta)}$ は $(0, \rho)$ 要素となる。

$$
\begin{aligned}
& l=R h+q\left\{\begin{array}{l}
h=0, \pm 1, \pm 2 \cdots \\
1 \leq g<R \text { なる奇数 }
\end{array}\right. \\
& \nu=\chi R-(m S+g)+1, \quad \xi=\chi R-g+1 \\
& O=\chi R+(m S+g)+1, \rho=\chi R+g+1 \\
& L_{2 m s}=\sum_{n=0}^{\infty} \sum_{h=-\infty}^{\infty} \frac{R}{2} \frac{u r}{2 \pi} P_{m S n R} \\
& \times \sin (h R+g) \frac{\pi}{2} /(h R+g)
\end{aligned}
$$




$$
\begin{aligned}
& \times\left\{\frac{\sin \frac{(m S+n R+h R+g) \pi}{2}}{m S+n R+(h R+g)} \cdot \varepsilon^{j n R \beta}\right. \\
& \left.+\frac{\sin \frac{(m S-n R+h R+g) \pi}{2}}{m S-n R+(h R+g)} \cdot \varepsilon^{-j n R \beta}\right\}
\end{aligned}
$$

固定子，回転子巻線間の相互インピーダンスを対称 座標変換すると $(20)$ 式となる。

$$
\begin{aligned}
{\left[M_{A}\right]=} & \sum_{m n l} \frac{\sqrt{3 R}}{2} \\
& \times\left\{M _ { ( m S \pm n R ) l } \cdot \left(\varepsilon^{j\left((m S+l) \theta^{\prime}+(m S \pm n R+l) \beta\right\}}\right.\right. \\
& \times\left[C_{\zeta \delta}\right]+\varepsilon^{-j\left((m S+l) \theta^{\prime}+(m s \pm n R+l) \beta\right\}} \\
& \left.\times\left[C_{n \varepsilon}\right)\right)+M_{(m S \pm n R) l^{\prime}} \\
& \times\left(\varepsilon^{\left.j(m S-l) \theta^{\prime}+(m S \pm n R-l) \beta\right)} \cdot\left[C_{\ell \varepsilon}\right]\right. \\
& \left.\left.+\varepsilon^{-j\left((m S-l) \theta^{\prime}+(m S \pm n R-l) \beta_{1}\right.} \cdot\left[C_{k \delta}\right]\right)\right\}
\end{aligned}
$$

$$
\left.\begin{array}{l}
\delta=3 \chi-l+1, \quad \varepsilon=3 \chi+l+1 \\
\zeta=\chi R-(m S \pm n R+l)+1 \\
\eta=\chi R+(m S \pm n R+l)+1 \\
\iota=\chi R-(m S \pm n R-l)+1 \\
\kappa=\chi R+(m S \pm n R-l)+1
\end{array}\right\}
$$

但し, $3 \geqq \delta, \varepsilon \geqq 1, R \geqq \zeta, \eta \cdots \kappa \geqq 1$

(21)式より, lが 3 の倍数であると一列の要素となり， 固定子零相回路との結合成分となる。

相互インダクタンスの高調波次数を $(6 h+1)$ とお き(20)式を整理すると, $M_{(6 h+1)} \varepsilon^{-j(6 h+1)(\theta++\beta)}$ は(

2) 要素, $M_{(6++1)} \varepsilon^{j(6 h+1)\left(\theta^{\prime}+\beta\right)}$ は $(\xi, 3)$ 要素之なる。

$$
\nu=\chi R+(6 h+1)+1, \quad \xi=\chi R-(6 h+1)+1
$$

$$
\begin{aligned}
M_{(6 h+1)}= & \sum_{m=0}^{\infty} \sum_{n=0}^{\infty} \frac{\sqrt{3 R}}{2} \cdot \frac{w u r}{\pi} P_{m s n R} \\
& \times\left\{\frac{k_{d}(6 h+1+m S)}{6 h+1+m S} \sin \right. \\
& \times \frac{(6 h+1+m S) \pi}{2}+\frac{k_{d}(6 h+1-m S)}{6 h+1-m S} \\
& \left.\times \sin \frac{(6 h+1-m S) \pi}{2}\right\} \\
& \times\left\{\frac{\sin (6 h+1+n R) \pi / 2}{6 h+1+n R} \cdot \varepsilon^{j n R \beta}\right. \\
& \left.+\frac{\sin (6 h+1-n R) \pi / 2}{6 h+1-n R} \varepsilon^{-j n R}\right\}
\end{aligned}
$$

空げきパーミアンス分布の变化が, 各次数のインダ クタンス成分に与える影響は，スロットの形状，みぞ
数，高調波次数により異なる。実験に用いた二極あた りのみぞ数が 20 の電動機について，相互インダクタ ンスの 17 次を例に示すと次のようになる。(23)式に おいて $m, n$ は1までとすればよいので，

$$
\begin{aligned}
M_{(-17)}= & \frac{\sqrt{3 R}}{2} \cdot \frac{w u r}{\pi} \times\left\{0.0133 P_{00}\right. \\
& +0.110 P_{S 0}+0.0346 P_{0 R} \\
& \left.+0.286 P_{S R}\right\}
\end{aligned}
$$

となる。第 1 項が起磁力分布に含まれる 17 次成分に よる項であり，他の 3 項は空げきパーミアンス分布の 变化倠よる成分である。パーミアンス分布は第 6 表の ようになるのでこれを㖕算すると，17 次成分は起磁 力の高調波のみを考慮した場合の約 5.3 倍となる。

\section{4. 電压方程式}

電源電㭱は平衡し，固定子巻線は星形結線で中性 線は非接続なので零相回路を除き, 固定子正相回路に 流れるすべり周波数の電流は無視しうると仅定する $之^{(6)(7)}$, 電圧方程式は (24) (26) 式となる。但し, 定 常状態であるのでべクトル記号法を用いている。

$$
\begin{aligned}
\dot{E}_{f}= & Z_{f}(j \omega) \cdot \dot{I}_{f}+\sum_{h} j \omega L_{1(3 h+1) R} \cdot \dot{I}_{b(3 h+1) R} \\
& +\sum_{k} j \omega M_{(6 k+1)} \cdot \dot{I}_{(6 k+1)} \ldots \ldots \ldots \ldots(24) \\
0= & j \omega_{1} L_{1(3 h+1) R} \cdot \dot{I}_{f}+Z_{b\left(j \omega_{1}\right) \cdot \dot{I}_{b(3 h+1) R}} \\
& \left.+\sum_{k} j \omega_{1} M_{(6 k+1)} \cdot \dot{I}_{(3 h+1} \cdot R-\overline{6 k+1}\right)
\end{aligned}
$$

$$
\begin{aligned}
0= & \left.j \omega_{2} M_{(6 k+1)} \cdot \dot{I}_{f}+\sum_{h} j \omega_{2} M_{(\overline{3 h+1}} \cdot R-\overline{6 k+1}\right) \\
& \times \dot{I}_{b(3 h+1) R}+\sum_{m} j \omega_{2} L_{2 m S} \cdot \dot{I}_{(\overline{6 k+1} \pm m S)} \\
& +Z_{2}\left(j \omega_{2}\right) \cdot \dot{I}_{(\hat{k} k+1)} \quad \ldots \ldots \ldots \ldots \ldots \ldots(26)
\end{aligned}
$$

但し, $\omega_{1}=\omega-(3 h+1) R \omega^{\prime}, \omega_{2}=\omega-(6 k+1) \omega^{\prime}$

$\omega, \omega^{\prime}$ : 電源, 電動機角周波数, $\dot{I}_{f}$ : 固定子 正相電流, $\dot{I}_{b(3 h+1) R}$ : 固定子逆相 $(3 h+1) R$ 次電流, $\dot{I}_{(6 k+1)}$ : 回転子 $(6 k+1)$ 次電流, $\dot{E}_{f}:$ 正相電圧, $Z_{f}(j \omega), \quad Z_{b}\left(j \omega_{1}\right), Z_{2}\left(j \omega_{2}\right)$ : 固定子正相, 固定子逆相, 回転子回路の自己 インピーダンス

(24)式は固定子正相回路の電圷方程式，(25) (26) 式 は固定子逆相の $(3 h+1) R$ 次, 回転子の $(6 k+1)$ 次 すべり周波数回路の電王方程式である。回転子みぞの 存在により固定子逆相回路に $(3 h+1) R$ 次すべり周波 数電流が流れ，固定子みぞの存在に上り回転子の各す ベり周波数回路が相互に結合されている(12)。

$\dot{I}_{b R}$ は $\dot{I}_{f}$ と比較して非常に小さい值を有するが， 相互インダクタンスの基本波分 $M_{1}$ を介して回転子の 
$(R+1)$ または $(R-1)$ 次すべり周波数回路に大きな 影響を与える。回転子のすべり周波数回路を相互に結 合する成分である $L_{2 S}$ は，基本波とみぞ高調波成分を 結合するむのが大きい値を有する。電流解は上式の連 立方程式を解けばよいが，回転子のすべり周波数電流 の成分として $(s \pm 1)$ 次および $(R \pm 1)$ 次，固定子逆 相のすべり周波数電流は $R$ 次考考慮す机ば十分であ る。

同期トルク発生時には，固定子逆相の $(3 K+1) R$ 次すべり周波数電流(但し $K$ は(32)式で表わされる) の周波数が電源周波数と等しくなり，固定子電流は負 荷争によって変化する。

\section{5. トルク}

瞬時トルクは(27)式で表わされる(4)。

$$
\tau_{i}=\frac{1}{2 \omega^{\prime}}[i], \frac{d\left[L_{S}\right]}{d t}[i]
$$

電流は瞬時値対称分表示注よって表わされ（28）（30) 式となる。

$$
\begin{aligned}
i_{f}= & \dot{I}_{f} \varepsilon^{j \omega t}+\sum_{h} \dot{I}_{b(3 h+1)} *_{R} \varepsilon^{-j\left(\omega-(3 h+1) R \omega^{\prime}\right) t} \\
i_{b}= & i_{f} * \ldots \ldots \ldots \ldots \ldots \ldots \ldots \ldots \ldots \ldots \ldots \ldots \ldots \ldots \ldots \ldots \ldots \ldots \ldots \ldots \ldots \ldots \\
i_{g}= & \sum_{h} \dot{I}_{(6 h+1)} \varepsilon^{j\left\{\omega-(6 h+1) \omega^{\prime}\right\} t} \\
& +\sum_{k} \dot{I}_{(6, k+1)} * \varepsilon^{-j\left(\omega-(6 k+1) \omega^{\prime}\right\} t}
\end{aligned}
$$

但L， $i_{f}$ : 固定子正相電流， $i_{b}$ : 固定子逆相電 流， $i_{g}:$ 対称座標軸上の回転子 $g$ 相電流 $i_{\sigma}$ についての和は次式を満足する $h, k$ について取る もの之する。

$$
g=\chi R+(6 h+1)+1, \quad g=\chi R-(6 k+1)+1
$$

平均トルク侍間に無関係な項をとればよく，(31) 式となる。高調波同期トルク $\dot{\tau}_{\text {sym }}$ は (33)〜 (38) 式, 高調波非同期卜ルク $\dot{\tau}_{a s y n}$ は (40) (43)式である。

$$
\tau=-2 \mathfrak{J}_{m}\left\{\sum_{m} \dot{\tau}_{s y m}+\sum_{n} \dot{\tau}_{a s y n}\right\}
$$

〈5・1〉高調波同期トルク高調波同期トルクは，

$$
K=\{2-(1-s) R\} / 3 R(1-s)
$$

が整数となるすべり $S$ で発生し，その他のすべりで は振動トルクとなる ${ }^{(6)}$ 。高調波同時トルクおよびトル クテンソル要素と電流要素の高調波次数の関係は次式 となる。

$$
\begin{aligned}
\dot{\tau}_{s y^{1}}= & \frac{1}{2}(3 K+1) R \cdot L_{1(3 K+1) R} \cdot \dot{I}_{f} * 2 \\
\dot{\tau}_{s y^{2}}= & \sum \frac{1}{2}(3 h+1) R L_{1(3 h+1) R} \cdot \dot{I}_{b(3 m+1) R} \\
& \times \dot{I}_{b(3 n+1) R} \ldots \ldots \ldots \ldots \ldots \ldots \ldots \ldots \ldots \ldots \ldots \ldots \ldots \ldots \ldots \ldots \ldots
\end{aligned}
$$

$$
\begin{aligned}
& n=K+h-m \ldots \ldots \ldots \ldots \ldots \ldots \ldots \ldots(34 \mathrm{a}) \\
& \left.\dot{\tau}_{s y^{3}}=\Sigma(6 h+1) M_{(6 h+1)} \cdot \dot{I}_{f^{*}} \cdot \dot{I}_{(6 m+1)}\right)^{*}(35) \\
& m=(3 R K+R-2) / 6-h \ldots \ldots \ldots \ldots \ldots(35 \mathrm{a}) \\
& \dot{t}_{s y^{4}}=\sum(6 h+1) M_{(6 h+1)} \cdot \dot{I}_{b(3 m+1) R} \cdot \dot{I}_{(6 n+1)}
\end{aligned}
$$

$n=h+R(K-m) / 2$

$\dot{\tau}_{s y 5}=\Sigma \frac{1}{2} h S \cdot L_{2 h S} \cdot \dot{I}_{(6 m+1)} \cdot \dot{I}_{(6 n+1)}$.

$$
m=(3 R K+R-2+h S) / 6-n
$$

トルクテンソル要素は $(\delta, \varepsilon)$ 要素

$\delta=\chi R-(6 n+1)+1, \quad \varepsilon=\chi R+(6 m+1)+1$

$$
\dot{\tau}_{s y^{6}}=\Sigma \frac{1}{2} h S \cdot L_{2 h S} \cdot \dot{I}_{(6 m+1)} * \cdot \dot{I}_{(6 n+1)} *
$$

$$
m=(3 R K+R-2-h S) / 6-n
$$

トルクテンソル要素は $(\delta, \varepsilon)$ 要䒺

$\delta=\chi R+(6 m+1)+1, \quad \varepsilon=\chi R-(6 n+1)+1$

（32）式を满足するすべりで発生する高調波同期トル クの中で最大のものは， $K=0$ となるすべりにおいて 発生するむのである。との場合の高調波同期トルクを 発生するすべりと回転子みぞ数の関係は第 1 表のよう

\begin{tabular}{|c|c|c|c|c|c|c|}
\hline 回転子み民数 & 2 & 8 & 14 & 20 & 26 & 32 \\
\hline 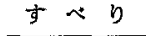 & 0 & $3 / 4$ & $6 / 7$ & $9 / 10$ & $12 / 13$ & $15 / 16$ \\
\hline 回転子みそ数 & 4 & 10 & 16 & 22 & 28 & 34 \\
\hline 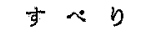 & $3 / 2$ & $6 / 5$ & $9 / 8$ & $12 / 11$ & $15 / 14$ & $18 / 17$ \\
\hline
\end{tabular}
になり， $R=6 l+2$ のみそ数估 $s<1$, 電動機としての 運転範囲において, $R=6 l+4$ のみぞ数では $s>1$, 制動 機としての運転範国で高調波同期トルクを発生する。

$\dot{\tau}_{s y 1} ， \dot{t}_{s y 2}$ は回転子にみぞが存在するために生じる トルクで，いわゆる反作用トルクである。これは $R$ 極 をむつ多相反作用電動機の発生するトルクと同じであ るが，すべりが 1 の付近で発生するために回転子回路 が短絡状態になり，大きな固定子電流が流入するの で，回転子みぞに上るパーミアンスの変化が小なのに 比較して大きな同期トルクとなる。

$\dot{\tau}_{s y 3}, \dot{\tau}_{s y 4}$ は固定子巻線電流化よる高調波磁束之回 転子巻線電流に上る高調波磁束が，波長が等しく，加 つ高調波磁束の回転速度が特定のすべりに扢いて等し くなることによって生じるトルクである。

第 1 表 回転子みぞ数と同期トルクを発生するずべり Table 1. Relation between the number of rotor slots and the slip genalating synchronous torque.

昭 54-1 
執行氏は，高調波同期トルクを発生する場合のすべ りと固定子磁束の高調波次数の関係を(39)式のように 表わしている(16)。

$$
\left.\begin{array}{l}
\frac{1}{n_{1}}=(1-S)-\frac{1-(1-S) n_{1}{ }^{\prime}}{n_{1}} \\
n_{1}+n_{1}{ }^{\prime}=-K N_{2} / p
\end{array}\right\}
$$

$n_{1}$ は相亘インダクタンスの高調波次数， $n_{1}^{\prime}$ は回転子 電流の高調浪次数之考元られるので， $\dot{r}_{s y s}$ が発生する すべり之高調波次数の関係は (39) 式を满足している。

$\dot{\tau}_{s y 5} ， \dot{\tau}_{s y 6}$ は固定子にみぞが存在するととによる磁 気回路の構造上の不均一性から生じるトルクであり， これあ反作用トルクであるる17)。但し，電流は外部電 源加ら直接供給されるのではなく，電磁㮇導により固 定子加ら供給される。

$\langle 5$-2〉高調波非同期トルク高調波非同期トル クと高調波次数の関係は次式となる。

$$
\begin{aligned}
& \dot{t}_{a s y 1}=\Sigma(3 h+1) R L_{1(3 h+1) R} \cdot \dot{I}_{f}^{*} \cdot \dot{I}_{b(3 h+1) R} \\
& \dot{\tau}_{a s_{y} z}=\Sigma(6 h+1) M_{(6 h+1)} \dot{I}_{f} * \cdot \dot{I}_{(6 h+1)} \ldots \text { (41) } \\
& \dot{\tau}_{a s y 3}=\Sigma(6 h+1) M_{(6 h+1)} \dot{I}_{b(3 m+1) R} \cdot \dot{I}_{(6 n+1)} * \\
& n=\{(3 m+1) R-2\} / 6-h \\
& \dot{\tau}_{a s y 4}=\sum h S L_{2 h S} \cdot \dot{I}_{(6 m+1)} \cdot \dot{I}_{(6 n+1)} * \ldots \text { (43) } \\
& m=n+h S / 6
\end{aligned}
$$

トルクテンソル要素は $(\delta, \varepsilon)$ 要素

$$
\delta=\chi R+(6 n+1)+1, \quad \varepsilon=\chi R+(6 m+1)+1
$$

$\dot{\tau}_{a s y 1}$ は固定子正相電流之逆相電流によるトルクで, 反作用トルクに付随するトルクである。この非同期ト ルクは，高調波同期トルクを発生する回転数の $1 / 2$ の 回転数において雾となる。

$\tilde{\tau}_{a s y 2}$ は起磁力に含まれる高調波のみを考慮したと きの高調波非同期トルクであり， $h=0$ は実用トルク である。各高調波トルクは $s=1-1 /(6 h+1)$ のすへりり において零となる。しかし，固定子巻線が分布巻であ ることおよびみぞの存在に上り，みぞ高調波成分が大 きなトルクとなる。

$\dot{\tau}_{a s y 3}$ は固定子逆相笔流之回転子電流に上るトルク

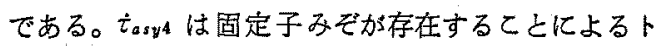

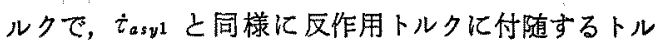
クである。

〈5・3〉みぞ数の組合せと高調波同期トルクの大きさ について 高調波同期トルクの大きさは，みぞ数の 組合せと密接な関係があり，特に回転子みぞ数と固定
子みぞ数の差が極数となる組合せの場合汇非常に大き な高調波同期トルクを発生することが従来から知られ ている。

$\langle 5.1\rangle$ 節で述べた高調波同期トルクのうちで，特定 のみぞ数の組合せを満足すると大きな高調波同期トル クとなる成分を含むむのは $\dot{\tau}_{s y 1}, \dot{t}_{s y 3}, \dot{t}_{s y 5}, \dot{t}_{s y 6}$ で ある。

$\dot{t}_{s y 1}$ の大きさはトルクテンソル要素 $L_{1(3 h+1) R}$ の大 きさによってほぽ決まり（14)式より $R=S \pm 2$ の場 合，大きな高調波同期トルクとなる。

$\dot{t}_{s y 3}$ は $R=S \pm 2$ の場合, 大きな高調波同期卜ルク となる。(35a)式に $K=0$ を代入すると(44)式となり, $S=18$ の場合乙の式を渶足する高調波次数は第 2 表之 なる。

$$
h+m=(R-2) / 6 .
$$

特にみぞ数の差が極数の場合，基本波とみぞ高調波の 組合せによるトルクが含まれ，乙の成分は他と比較し て非常に大きな高調波同期トルクとなる。

$\dot{t}_{s y 5}$ は回転子みぞ数が固定子みぞ数より極数だけ小 さい組合せの場合，大きな值となる。(37a)式に $K=0$ $h=1$ を代入すると(45)式となる。

$$
m+n=(R-2+s) / 6
$$

$s=18$ の場合，(45)式を満足する $R$ 之高調波次数の 関俰敒第 3 表の上うにはる。 $R=S-2$ の場合，(45) 式は $m+n=0$ となる。特に笔流要素が基本波の場合 のトルクテンソル要素は他の要素と此較して大きな值

\begin{tabular}{|c|c|c|c|c|c|c|c|c|c|c|}
\hline$s$ & $R$ & & -25 & -17 & -5 & 1 & 7 & 13 & 19 & 25 \\
\hline \multirow{3}{*}{18} & 1 & $6 h+1$ & 7 & & & & & {$[-29]$} & & \\
\hline & 20 & $2 C$ & 43 & 4 & 25 & 19 & 13 & 7 & & -5 \\
\hline & 22 & $-22-(6 h+1)$ & 1 & & & & & -35 & -41 & \\
\hline
\end{tabular}
を有するので $\hat{t}_{s y 5}$ は大きな高調波同期トルクとなる。 $\dot{\tau}_{s y 6}$ は回転子みぞ数が固定子みぞ数より極数だけ大 きい場合，大きな值となる。(38a)式に $K=0, h=1$ を代入すると(46)式となる。

$$
m+n=(R-2-S) / 6
$$

第 2 表 $\tau_{s y^{3}}$ 亿関する高調波の組合甘

Table 2. Combination of harmonics with respect to $\tau_{s y 3}$.

第 3 表 $\tau_{s, 5}$ 《関する高調波の組合せ

Table 3. Combination of harmonics with respect to $\tau_{s, y 5}$.

\begin{tabular}{r|r|l|r|r|r|r|r|r|r|r|r}
\hline$S$ & $R$ & $6 n+1$ & -23 & -17 & -11 & -5 & 1 & 7 & 13 & 19 & 25 \\
\hline \multirow{3}{*}{18} & -16 & $2-(6 m+1)$ & 25 & 19 & 13 & 7 & 1 & -5 & -11 & -17 & -23 \\
& 20 & $38-(6 m+1)$ & 61 & 55 & 49 & 43 & 37 & 31 & 25 & 19 & 13 \\
& -22 & $-4-(6 m+1)$ & 19 & 13 & 7 & 1 & -5 & -11 & -17 & -23 & -29 \\
\hline
\end{tabular}


第 4 表 $\tau_{s y 6}$ に関する高調波の組合せ

Table 4. Combination of harmonics with respect to $\tau_{s y \delta \text {. }}$

\begin{tabular}{r|l|l|r|r|r|r|r|r|r|r|l}
\hline$S$ & $R$ & $6 n+1$ & -23 & -17 & -11 & -5 & 1 & 7 & 13 & 19 & 25 \\
\hline \multirow{3}{*}{18} & 16 & $-34-(6 m+1)$ & -12 & -17 & -23 & -29 & -35 & -41 & -47 & -59 & -59 \\
& 20 & $2-(6 m+1)$ & 25 & 19 & 13 & 7 & 1 & -5 & -11 & -17 & -23 \\
& 22 & $-40-(6 m+1)$ & -17 & -23 & -29 & -35 & -41 & -47 & -53 & -59 & -65 \\
\hline
\end{tabular}

$S=18$ の場合， (46) 式を満足する $R$ と高調波次数の 関係は第 4 表のようになる。 $R=S+2$ の場合 (46) 式 は $m+n=0$ となり， $\dot{\tau}_{s y^{5}}$ と同様に大きな值となる。

\section{6. 計算と実験結果の比較}

実験に使用した誘導電動機は，4 極，固定子みぞ数 36 , 空げき長 $0.5 \mathrm{~mm}$ ，巻数 360 , 全節巻, 星形結線 のあのである。回転子は二極あたりのみで数が 20 お よび 22 二種について実軻を行なった。

固定子および回転子の各部の寸法㹥 5 䈉である。 パーミアンス分布は，尾本・石崎氏の方法により求ま り，結果第 6 表となり，両者の差はほとんどない。 実験は電壬 $80 \mathrm{~V}$ にて行ない，ひずみゲージ式トルク 変換器と速度計発電機を用い，X-Y レコーダにより 記録した。

第 2 困は，二極あたりの回転子みぞ数が 20 の場合 のトルク速度特性で, $s=0.9$ において大きな高調波 同期トルクを発生している。計算は回転子の高調波す ベり周波数電流のうち, $5,17,19$ 次を考虑している。

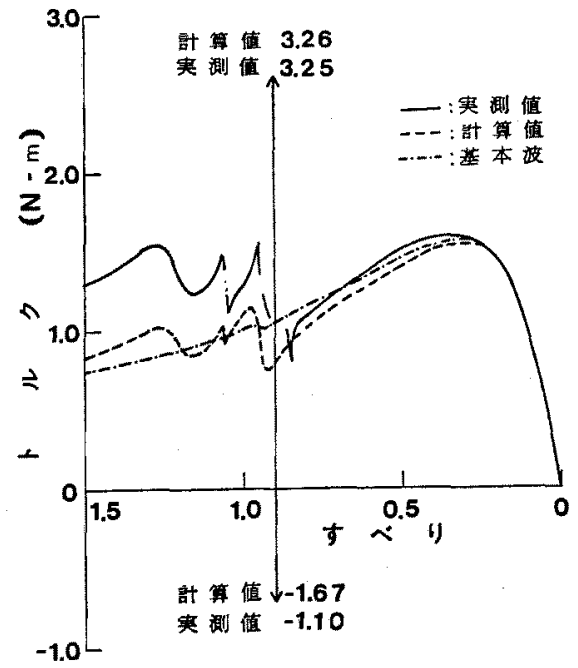

第 2 龱トルクー速度特性 (4P，36 固定子, 40 回転子スロット)

Fig. 2. Torque-speed characteristic. ( $4 P, 36$ stator and 40 rotor slots)
第 5 表 固定子亡回転子の寸法

Table 5. Stator and rotor size of the tested machine.

\begin{tabular}{|c|c|c|c|}
\hline & \multirow{2}{*}{ 固 定 子 } & 回 & 子 \\
\hline & & $R=20$ & $R=22$ \\
\hline 有奻㪘心悵 & $60.0 \mathrm{~mm}$ & $60.0 \mathrm{~mm}$ & $60.0 \mathrm{~mm}$ \\
\hline 内 (外) 蛋 & $111.0 \mathrm{~mm}$ & $110.0 \mathrm{~mm}$ & $110.0 \mathrm{~mm}$ \\
\hline みぞピッチ & 9. $68 \mathrm{~mm}$ & $8.64 \mathrm{~mm}$ & $7.91 \mathrm{~mm}$ \\
\hline みぞ開口輻 & 2. $53 \mathrm{~mm}$ & $1.39 \mathrm{~mm}$ & $1.45 \mathrm{~mm}$ \\
\hline 巻 数 & 360 turn & - & - \\
\hline
\end{tabular}

第 6 表 パーミアンス

Table 6. Permeance calculated from stator and rotor size.

\begin{tabular}{c|c|c|c|c|c}
\hline & $R=20$ & $R=22$ & & $R=20$ & $R=22$ \\
\hline$P_{00}$ & $0.730 \mu_{0} / 2 d$ & $0.728 \mu_{0} / 2 d$ & $P_{0 R}$ & $0.122 \mu_{0} / 2 d$ & $0.126 \mu_{0} / 2 d$ \\
$P_{S_{0}}$ & $0.254 \mu_{0} / 2 d$ & $0.253 \mu_{0} / 2 d$ & $P_{S R}$ & $0.0345 \mu_{0} / d$ & $0.0355 \mu_{0} / d$ \\
\hline
\end{tabular}

$d:$ 空げき鹿, $d:$ Gap length

$s=0.9$ にて発生する高調波同期トルクのうち大き な成分は，負荷角を $D$ とすると次式となる。

$$
\begin{aligned}
& \tau_{s y 1}=-20 \mathscr{I}_{m}\left\{L_{1 R} \dot{I}_{f}^{* 2} \varepsilon^{j 20 D}\right\} \quad \ldots \ldots \ldots \\
& \tau_{s y 3}=-38 \mathscr{I}_{m}\left\{M_{19} \dot{I}_{f}^{*} \cdot \dot{I}_{1}^{*} \varepsilon^{j 20 D}\right\} \\
& \tau_{s y 6}=-18 \mathscr{I}_{m}\left\{L_{2 s} \dot{I}_{1}^{* 2} \varepsilon^{j 20 D}\right\} \quad \ldots \ldots \ldots
\end{aligned}
$$

第3図は，二極あたりの回転子みぞ数が 22 の場合 のトルク速度特性で, $s=1.09$ に放いて高調波同期卜 ルクを発生している。計算は回転子の $5,17,19,23$ 次すべり高調波電流を考虑している。

画者のパーミアンス分布の差は非常に小さいが，高

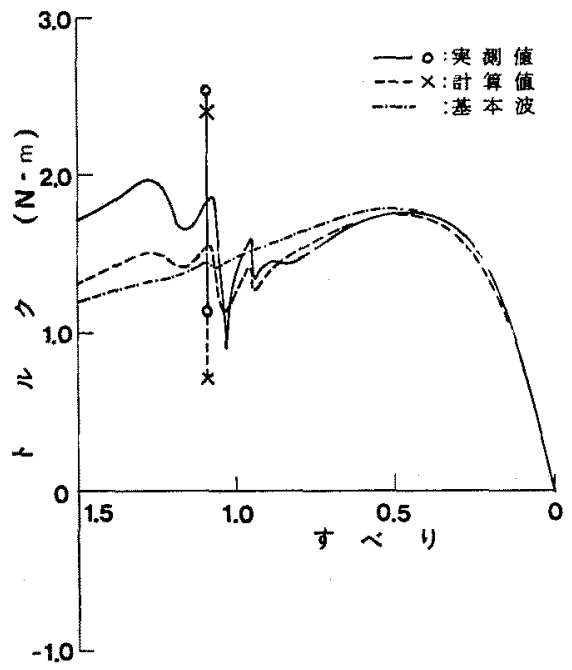

第 3 図 トルクー速度特性 $(4 P ， 36$ 固定子，44 回転子スロット)

Fig. 3. Torque-speed characteristic. (4P, 36 stator and 44 rotor slots) 
調波同期トルクに大きな差を生じるつは〈5・3〉節で 述べたように，R=20はみぞ数の差が極数となる組合 せであり，R=22はその他の組合せになるからである。 計算值と実測值の誤差は,

（1）パーミアンス分布，磁束密度分布の計算に拉 ける仮定によるむの

（2）漂遊挰，鉄損の無視によるもの

（3）発熱に上る巻線抵抗增大の制視によるすの

(4) 漏れインダクタンスの誤差によるもの などが考えられる。高調波同期トルクおよび非同期卜 ルクの誤差は书もに（1）による向のであろう。

\section{7. まとめ}

加ご形誘導電動機の高調波異常現象のうち，回転時 同期トルクを発生する場合について解析と実験を行な い満足すべき結果を得た。本研究の結果明らかになっ たことは次の点である。

（1）Kron 氏が電気機械のテンソル解析法を発表 後統一理論への空間高調波の導入は加藤氏などによっ てなされている。本研究は，ての手法へスロットの存 在による空げきパーミアンス分布の変化の影響を導入 し、スロットリップルの影響の大きいかで形誘導電動 機の高調波買常トルクの解析に有效な手法とした。

（2）高調波同期於よび非同期トルクの一般式を求 め，各高調波トルクの性質，回転子みそ数と同期トル クを発生するすべりの関係，および回転子みぞ数と高 調波トルクを発生する高調波次数の関係を明らかにし た。特に(32)式で表わされる $K$ を導入するてとによ り，トルクの一般式が，従来の解析結果より簡潔な形 で明確に表現できるようになった。

本解析法儿上れば，不平衡電源の場合もまた容易に 解析可能であるう。また，パーミアンス分布を求める

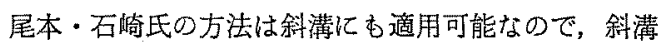
がトルク特性に及活す影響むまた解析可能であ万う。

電王方程式 (24) (26) より解析的に電流解が求まる のは (1) 回転子電流が雾, すなわ反作用電動機の 場合 ${ }^{(6)(7)}$ ，および (2) 相互誘導の高調波成分のみを 考慮した場合である。（1）の場合の電圧方程式は，微 分演算子を $P$ として (50)式（2)の場合は(51)式と なる。

固定子正相回路に流れる $6 n$ 次のすべり周波数電流を 無視すれば(7)，Harmonic Machineの理諭 ${ }^{(13)}$ と整流変

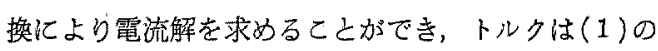
場合 $\left.\dot{\tau}_{s y 1}, \dot{\tau}_{s y 2}, \dot{\tau}_{a s y 1}, （ 2\right) の$ 場合は $\dot{\tau}_{s y 3}, \dot{\tau}_{a s y z}$ 之な る。

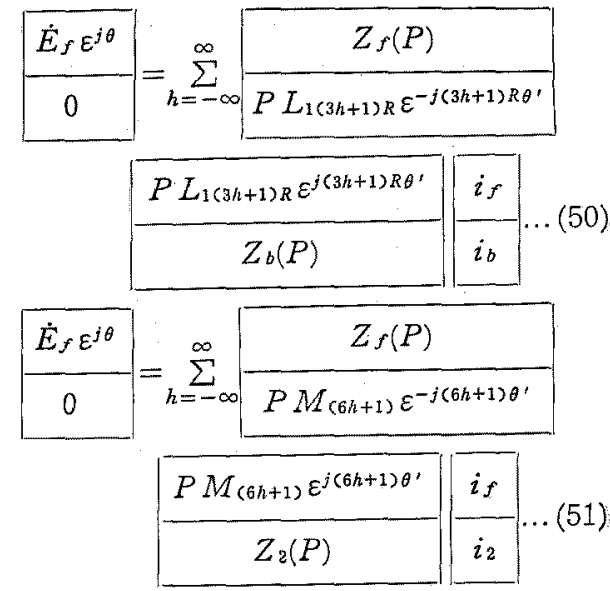

回転子みそ数が 6 の倍数，すなわち静止時同期トル クを発生する場合は，対称座標変換した固定子巻線の 自己インダクタンスはすべて刘角要素となり，正相回 路にすべり周波数電流を流すので解を得るのが困難に なり，今㣪の課題となる。

終りに，種々ので指摘，で助言をいただいた秋田大 学鉱山学部井上利夫, 赤上隄出男両教授汇深く感謝し ます。

(昭和 53 年 1 月 9 日受付，同 53 年 8 月 2 日再受付)

\section{文献}

(1) G.K. Kron: The Application of Tensors to the Analysis of Rotating Electrical Machinery G. E. Rev. 36 , 181 (1935)

(2) Gibbs: Tensors in Electical Machine Theory Chapman and Hall (1952)

(3) C. V. Jones: The Unified Theory of Electrical Machines Butterworth

(4) 竹内: Matrix Theory of Electrical Machinery(オーム社)

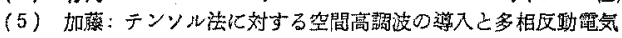

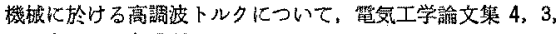
151 (昭和 27 年 5 月)

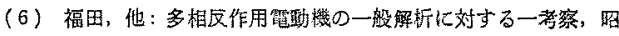

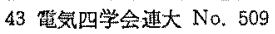

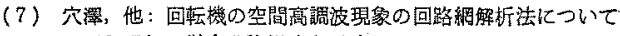
昭 46 篦気四学会北祩道支部連大 50

(8) Y. Saito: The Theory of the Harmonics of the $m, n$ Symmetical Machine E.T,Z-A 95, 10, 526 (19?4)

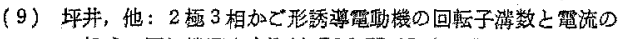
一般式，回枟涉研究会盗料 RM-77-15（昭 52-10)

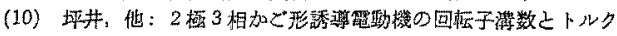
の一般式，回枟機研究会資料 RM-77-16（昭 52-10）

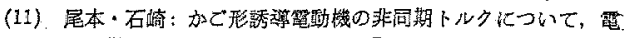
気工等論文集 4，3，127(昭和 27-5)

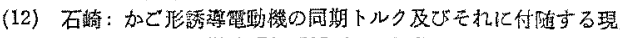
象以ついて, 電学殸 74,705 (昭 29-6)

(13) M. Jevons: Electrical Machine Theory p. 304, Blackie

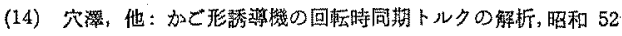
年電知学会全国大会 861

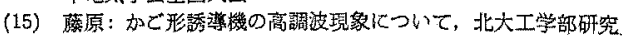
報告第 24 号 (骂 36-2)

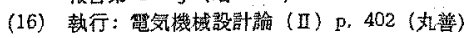

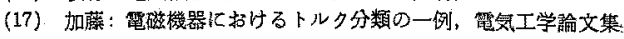
4, 4, 185 (昭 27-7) 